\title{
RESGATANDO A RELAÇÃO ENTRE O ENSINO DA LITERATURA E O DESENVOLVIMENTO HUMANO
}

\author{
Flaviana Bataliotti Gomes ${ }^{1}$, Ricardo Eleutério dos Anjos ${ }^{2}$ \\ ${ }^{1}$ Mestranda em Educação Escolar pela Universidade Estadual Paulista (UNESP), campus de Araraquara-SP. E-mail: \\ flavianabgomes@gmail.com \\ ${ }^{2}$ Doutor em Educação Escolar pela Universidade Estadual Paulista (UNESP), campus de Araraquara. Atualmente é \\ docente do Programa de Pós-Graduação em Educação e do curso de Graduação em Psicologia da Universidade do \\ Oeste Paulista (Unoeste).
}

\section{RESUMO}

A hegemonia das teorias pedagógicas na educação tem-se vinculado à ideia de que o processo de desenvolvimento humano não está relacionado aos conteúdos escolares. Com isso, o artigo objetivou resgatar uma visão histórica do homem, entendendo-o como um ser social e em constante transformação de si mesmo e da sociedade e, dentro dessa perspectiva, a literatura como clássico torna-se memória da humanidade e, concomitantemente, reflete no desenvolvimento pessoal de cada indivíduo estabelecendo uma importante relação entre ambos dada pela catarse. Entender o fenômeno da catarse, bem como a arte e a literatura como instrumento do movimento dialético entre universal-singular-particular é enfatizar sua importância para a continuidade da vida de cada homem e da sociedade a qual pertence, em um constante processo de ser produto e produtor da sua história e sua História.

Palavras-chave: Literatura; psicologia histórico-cultural; desenvolvimento humano.

\section{RESCUING THE RELATIONSHIP BETWEEN LITERATURE AND HUMAN DEVELOPMENT}

\begin{abstract}
The hegemony of the pedagogical theories on education has been linked to the idea that the process of human development isn't related to the school content. Regarding this, the article seeks to redeem the hystorical vision of man, as a social being and in constant transformation of the self and of society and, in this perspective, the literature as a classic, becomes humanship's memory and, concomitantly, reflects on the psrsonal development of each individual, establishing an important relation between both by catharsis. To understand the phenomenon of the catharsis, as well as the art and the literature as an instrument of the dialetical way between universal-single-particular is to emphasize its importance to the continuity of life of each mean and the society which he belongs, in a constant process of being product and producer of its story and its History.
\end{abstract}

Keywords: Literature; historical cultural psychology; human development

\section{RECUPERACIÓN DE LA RELACIÓN ENTRE LA EDUCACIÓN EN LITERATURA Y EL DESARROLLO HUMANO}

\section{RESUMEN}

La hegemonía de las teorías pedagógicas en la educación se ha vinculado a la idea de que el proceso de desarrollo humano no está relacionado con los contenidos escolares. Con eso, el artículo objetivó rescatar una visión histórica del hombre, entendiéndolo como un ser social y en constante transformación de sí mismo y de la sociedad y, dentro de esa perspectiva, la literatura como clásico se convierte en memoria de la humanidad y, concomitantemente, refleja en el desarrollo personal de cada individuo estableciendo una 
importante relación entre ambos dada por la catarsis. Entender el fenómeno de la catarsis, así como el arte y la literatura como instrumento del movimiento dialéctico entre universal-singular-particular es enfatizar su importancia para la continuidad de la vida de cada hombre y de la sociedad a la que pertenece, en un constante proceso de ser producto y productor de su historia y su Historia.

Palabras Clave: Literatura; Psicología Historico Cultural; Dessarollo Humano

\section{INTRODUÇÃO}

Atualmente, nas concepções escolares, há uma hegemonia das teorias pedagógicas pautadas no lema "aprender a aprender", vinculando-o sempre a julgamentos positivos. $O$ lema em questão pauta-se na ideia de que o aluno desenvolva a capacidade de realizar aprendizagens significativas por si só, dentro de situações que voltam-se à sua máxima: "aprenda a aprender" (DUARTE, 2001). Ou seja, de acordo com Duarte (2001), existiriam quatro posicionamentos valorativos contido no lema "aprender a aprender". O primeiro posicionamento valorativo é o de que aprender sozinho é melhor do que aprender com outras pessoas. O segundo posicionamento defende a ideia de que é mais importante o aluno desenvolver um método de aquisição ou construção de conhecimentos do que esse aluno aprender os conhecimentos socialmente produzidos por outras pessoas. O terceiro posicionamento valorativo é o de que a atividade educativa deve ser dirigida pelos interesses e necessidades do aluno. $\mathrm{O}$ quarto posicionamento é o de que a educação escolar deve levar o aluno a "aprender a aprender", preparando o indivíduo a acompanhar a sociedade em acelerado processo de mudança.

Para Vigotski (2010), concepções do gênero partem do pressuposto de que o processo de desenvolvimento é independente daquilo que se aprende na escola e não levam em conta que a sociedade e a natureza do homem estão conectadas de tal forma que não podem ser separadas.

O homem é um ser social e tudo o que há de humano, propriamente dito, foi construído a partir da vida em sociedade e, por isso, é preciso que cada homem aprenda a sê-lo por meio do processo dialético de apropriação e objetivação da cultura (DUARTE, 2008). É nesse sentido que, quando Saviani (2011) pontua a escola como uma instituição que deve basear-se no saber metódico e sistematizado, - ou o saber clássico para possibilitar seu acesso ao ser humano, o autor evidencia a natureza e a especificidade da educação, aproximando-os do processo supracitado de apropriação e objetivação do conhecimento historicamente acumulado. Portanto, sendo o papel da escola a transmissão e apropriação do conhecimento sistematizado, em última instância, ela possibilita o desenvolvimento humano.

Ainda, é importante ressaltar que diferentemente do que é levantado nos posicionamentos valorativos do lema "aprender a aprender", o ensino não deve estar somente relacionado ao que o estudante já sabe, mas sim, atuar na Zona de Desenvolvimento Próximo e exigir mais do que pode atuar para que consiga superar a si mesmo. Um ensino que pauta-se nas capacidades iminentes do aluno está à frente do desenvolvimento deste e o impulsiona (ANJOS, 2013).

Tendo isso como base, este artigo busca trazer uma aproximação entre a pedagogia histórico-crítica, a psicologia histórico-cultural e os pressupostos filosóficos de Lukács, para fins de análise da relação entre o ensino da literatura e o desenvolvimento humano. Para tanto, o objetivo deste artigo foi resgatar uma visão histórica de homem, entendendo-o como um ser social e em constante transformação de si mesmo e da sociedade e, dentro dessa perspectiva, a literatura como clássico torna-se memória da humanidade e, concomitantemente, reflete no desenvolvimento pessoal de cada indivíduo estabelecendo uma importante relação entre ambos dada pela catarse.

\section{A DIALÉTICA NA FORMAÇÃO DO PSIQUISMO}

A psicologia histórico-cultural entende o homem a partir do materialismo histórico dialético e por sua vez, busca superar concepções endógenas, idealistas e dicotômicas que endossam a divisão "mente e corpo" que existe na psicologia tradicional, bem como a psicologia que pauta-se no mecanicismo e evolucionismo (LEONTIEV, 1978; LURIA, 1979). 
Entender o homem a partir de uma visão histórica e cultural é entendê-lo como um ser qualitativamente diferente dos outros animais, visto que não bastam suas características biológicas transmitidas geneticamente, mas de tudo que produziu em sociedade e transmitiu ao longo da história. $\mathrm{O}$ homem criou sua vida em sociedade por meio da modificação da natureza e, concomitantemente, modificou suas atividades mentais por meio dela (LEONTIEV, 1978).

A modificação da natureza engendrou no homem necessidades cada vez mais complexas, e estas, foram capazes de gerar ferramentas e signos no mundo cada vez mais elaboradas e estruturadas, atividade que tornouse vital para o desenvolvimento humano e distinguiu $\mathrm{o}$ homem dos demais animais (LEONTIEV, 1978).

Em suma, o homem modifica a natureza e simultaneamente, transforma e cria também a sua própria, sendo capaz de transmiti-la às outras gerações. Por isso que, para tornar-se humano, não bastam as características biológicas, é preciso apropriar-se e objetivar-se do conhecimento historicamente acumulado para dar continuidade à este processo de modificação da natureza, que deu-se início nos primórdios da humanidade, e mantém-se presente até os dias de hoje devido a esse processo. Por isso, afirma Leontiev (1978, p. 267):

Podemos dizer que cada indivíduo aprende a ser um homem. O que a natureza lhe dá quando nasce não lhe basta para viver em sociedade. É-lhe ainda preciso adquirir o que foi alcançado no decurso do desenvolvimento histórico da sociedade humana. O indivíduo é colocado diante de uma imensidade de riquezas acumuladas ao longo dos séculos por inumeráveis gerações de homens, os únicos seres, no nosso planeta, que são criadores. As gerações humanas morrem e sucedem-se, mas aquilo que criaram passa às gerações seguintes que multiplicam e aperfeiçoam pelo trabalho e pela luta as riquezas que lhes foram transmitidas e "passam o testemunho" do desenvolvimento da humanidade.

Essa atividade, que é vital para o desenvolvimento humano, é denominada trabalho, e exigiu do homem domínios cognitivos imprescindíveis para a construção de uma representação mental da realidade, ou seja, de um psiquismo, uma vez que os objetivos de sua atividade são antecipados mentalmente e superados à medida que domina a natureza, fazendo com que sua estrutura, a priori, somente biológica, se torne especificamente humana ao longo desse processo (MARTINS, 2015).

Esta atividade fez com que as necessidades do homem passassem a ser sociais, e por isso, exigiu um psiquismo cada vez mais sofisticado como reflexo de necessidades supridas e das que ainda estão por vir (MARTINS, 2015). Em última instância, o homem entrou em um processo de superação de si mesmo, uma vez que se expandiu, permaneceu e permanece nesse ciclo por meio da transmissão, apropriação e objetivação a partir do que foi apropriado.

Luria (1979), dentro dessa lógica, traz uma definição pertinente aos assuntos supracitados até então: a diferenciação da atividade dos animais com a atividade consciente do ser humano. Ora, se a atividade agora é regida por necessidades sociais, ou seja, mediadas, o ser humano está para além do imediatismo do fenômeno e é capaz de buscar um conhecimento mais profundo das leis que permeiam as situações, ou seja, torna a sua atividade consciente.

Importante ressaltar que essas concepções podem ocasionar alguns equívocos, se mal interpretadas. A psicologia históricocultural não pactua com a ideia de que o biológico não se faz importante no entendimento do psiquismo e da atividade consciente do homem, uma vez que esses dois só são capazes de se formar a partir dessa estrutura biológica. Por isso que, em última instância, o psiquismo é a representação mental, que acontece no cérebro, da realidade objetiva. Esta representação se desenvolve a partir da complexificação dos organismos e uma vez que a cultura criada pelo humano preexiste aos seres, há a reconstituição do organismo por meio da atividade (MARTINS, 2013). Trazer isto à tona é visar diretamente 
àquilo que Vigotski (1995) chamou de Lei Genética Geral do Desenvolvimento Cultural, a qual postula que:

(...) toda função entra em cena duas vezes, em dois planos, primeiro no plano social e depois no psicológico, ao princípio entre os homens como categoria interpsíquica e logo no interior da criança como categoria intrapsíquica (VIGOTSKI, 1995, p. 150).

A citação acima se refere às suas concepções de que as características biológicas estabelecidas através da evolução das espécies se denominam como funções psíquicas elementares e são comuns a todos os homens, tais como: sensação, percepção, atenção involuntária, entre outras. Sendo passíveis de serem desenvolvidas, as funções elementares tornam-se sistemas mediados por signos, e, complexificam-se a partir do processo dialético de superação por incorporação, desenvolvendo-se no que Vigotski (1995) chamou de "funções psíquicas superiores" (MARTINS, 2015).

De acordo Martins (2015), o signo, que é uma forma de mediação para com o mundo, criada socialmente em meio a adaptação e transformação da natureza, tem um caráter interpositivo e sua atuação se dá a partir da adaptação a eles, agindo sobre as funções psíquicas e transformando suas expressões espontâneas em expressões volitivas e culturais (humanas).

Por meio de mediações transpassadas às necessidades sociais, as funções psíquicas superam-se e transformam-se em funções psíquicas superiores. Importante enfatizar que, no entanto, não há separação entre funções psíquicas elementares e superiores. O que acontece é uma fusão entre uma e outra, por meio de um processo de superação por incorporação, isto é, embora sejam superadas, as elementares nunca são eliminadas da vida (MARTINS, 2015). É relativo a esse sentido que Lukács (2013) postula que o trabalho evidenciou uma superação do ser meramente biológico sem, todavia, eliminá-lo.

Por conseguinte, há um processo concomitante e dialético entre funções psíquicas superiores e o engendramento de novas necessidades, no qual, a apropriação e objetivação dos conhecimentos filosóficos, artísticos e científicos manifestam-se, não só como desenvolvimento das funções psíquicas, mas como uma necessidade que, a partir da incorporação da história humana, passa a fazer parte da história do indivíduo (ANJOS, 2017).

Em síntese, é por isso que Vigotski (1995) pontua que as relações interpsíquicas passam a constituir o próprio psiquismo e tornam-se parte da criança, de forma intrapsíquica, uma vez que, essa relação dela com o outro - que não deve ser entendida fora da síntese dialética da relação entre ambos - é internalizada e a desenvolve.

Desse modo, estabelecido que a apropriação da cultura acontece de forma historicamente instituída e que para Vigotski não há desenvolvimento sem educação, é possível pensar em estreitas relações entre psicologia e o processo educativo, uma vez que a principal tarefa deste último é transmitir ao aluno aquilo que ele não aprenderia por si só, visto que precisa da superação por incorporação. Assim sendo, cabe à educação transmitir signos construídos historicamente para que possam se tornar intrapsíquicos e complexificar o psiquismo (MARTINS; RABATINI, 2011).

A educação, por fim, se torna provedora dos instrumentos necessários à humanização, à superação dos limites naturais e das maneiras de lidar com a sociedade, de forma que o aluno se torne sujeito e não sujeitado às suas condições externas. É por esse motivo que esta instituição deve promover as formas sociais mais elaboradas e complexas do comportamento, para que se tornem meios pessoais de relação com o mundo e para consigo mesmo (MARTINS; RABATINI, 2011).

\section{POR QUE O CLÁSSICO É IMPORTANTE NA EDUCAÇÃO?}

Saviani (2006) criou sua teoria partindo do materialismo histórico-dialético e em sua análise das teorias pedagógicas, traz dois conjuntos de teorias antagônicas que são capazes de mostrar, a partir do problema da marginalidade, a maneira como existe uma recíproca entre desenvolvimento humano e a educação escolar.

O primeiro conjunto, denominado de "Teorias Não Críticas", é formado por: a) Escola Tradicional; b) Escola Nova; e c) Escola Tecnicista. Já o segundo conjunto, o qual Saviani denominou 
de "Teorias Crítico-Reprodutivistas" constitui-se de: a) Teoria do Sistema de Ensino Enquanto Violência Simbólica; b) Aparelho Ideológico do Estado; e c) Teoria da Escola Dualista. As primeiras denominam-se deste modo, pois entendem a educação como um meio de equalização social e correção da marginalidade. Já as segundas, entendem as determinações sociais na escola, mas são reprodutivistas, à medida que, reproduzem essas relações e não buscam um meio de saída para esse sistema de educação (SAVIANI, 2006). Nesse artigo, serão dissertadas sobre as teorias não críticas para melhor compreensão dos objetivos aqui propostos.

A Escola Tradicional foi o primeiro modelo a ser utilizado no início da sociedade moderna e caracterizava-se por entender o problema da marginalidade como "o ignorante", visto que somente vencendo este "erro" superariam a opressão do Antigo Regime. Por isso que tal pedagogia pautava-se somente na assimilação e transmissão dos conhecimentos, uma vez que seu objetivo era corrigir a ignorância dos cidadãos (SAVIANI, 2006).

A Escola Nova, por sua vez, surgiu para contrapor este modelo considerado por muitos como autoritário e desumano, uma vez que se baseavam na ideia de passividade dos alunos dando ênfase ao professor. Para esta visão, o problema da marginalidade é "o rejeitado" e para a "correção" de tal questão, a Escola Nova pautou-se em métodos que enfatizavam o aluno e seus interesses, em que o professor é somente um orientador e guia em suas aprendizagens. Interessante salientar que essa mudança veio dos novos estudos da época centrados na psicologia e nas diferenças de cada um, mas indo contra suas próprias propostas, este movimento potencializou o problema da marginalidade, uma vez que não garantiu o acesso da educação à maioria da população (SAVIANI, 2006).

Por fim, a Escola Tecnicista visava o problema da marginalidade como "o improdutivo", tendo em vista que suas ideias pautavam-se no ensino técnico e objetivo para aumentar a produção dos operários, uma vez que este movimento surgiu na Revolução Industrial (SAVIANI, 2006).

Buscando superar estas teorias, bem como as que foram citadas, mas não aprofundadas neste trabalho, Saviani formulou uma nova teoria, com a proposta de voltar a educação para a conscientização e a prática social, especialmente para a classe trabalhadora.

Essa perspectiva pedagógica entende a natureza do homem como social e advinda do trabalho e com isso, mostra que falar sobre educação é também refletir sobre aquilo que separa o ser humano dos demais animais, uma vez que ela é um processo de trabalho, bem como exigência do e para o mesmo. Diferentemente dos demais animais, o homem criou sua existência e a transmitiu ao longo do tempo, de forma que, concomitantemente e consequentemente, complexificou seus bens materiais, seu entendimento sobre o mundo e também a si mesmo (SAVIANI, 2011).

Se a natureza do homem não é dada e sim produzida historicamente pelos próprios homens, cabe, portanto, a eles intermediarem e produzirem em cada pessoa a humanidade que Ihe é própria (SAVIANI, 2011) Assim, a educação deve buscar o ato de originar a humanidade que é produzida historicamente em cada indivíduo, de forma direta e intencional. Em última instância, é preciso que a educação torne o homem contemporâneo à sua época, tendo em vista que quando nasce, já está fadado a encontrar-se em um contexto histórico que é produto da história (SAVIANI, 2013).

De forma semelhante à psicologia histórico-cultural, Saviani (2011) pontua que o homem não só se adapta à natureza, mas também a adapta a partir de suas necessidades. Assim, cria, em escalas cada vez mais complexas, os bens materiais necessários para sua produção de existência, os quais serão categorizados como "trabalho material". Mas como colocado, antes de sua produção, é preciso que haja a antecipação das ideias enquanto objetivos da ação, e para tal ato, é necessário o conhecimento do mundo real (ciência), da valorização (ética) e de simbolização (arte), os quais se encontram no estrato de "trabalho não-material" (SAVIANI, 2011).

Envolto a isso, Saviani (2011) aponta que a educação se encontra neste último setor de trabalho, já que é alusiva a ideias, conhecimentos, conceitos, valores, símbolos, etc. e a escola situa-se dentro de uma prática global social. Ora, se tais concepções caracterizam a natureza da educação, entendê-la é visar diretamente sua especificidade: levar a apropriação da realidade para cada indivíduo e buscar as formas mais adequadas para este fim. 
Diante disso, é importante ter em mente três palavras que os gregos remetem ao

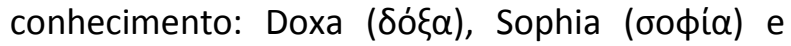

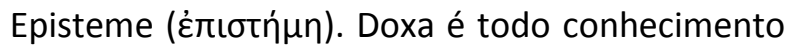
advindo do senso comum e da experiência cotidiana; Sophia está relacionado ao conhecimento adquirido pela experiência de vida; e por fim, Episteme é o conhecimento metódico e sistematizado (SAVIANI, 2011).

De acordo com Saviani (2011), a escola deve se organizar para garantir a transmissão deste último, bem como assegurar o acesso aos instrumentos que possibilitam o domínio deste saber. E é por isso que esta instituição deve pautar-se no problema da ciência e entender 0 que é conhecimento clássico, o erudito, ou o que o próprio autor denominou: aquilo que ficou como fundamental à espécie humana, pois é por meio deste conhecimento que o indivíduo tem acesso às criações mais desenvolvidas do ser humano e a apropriação destes modelos que torna toda e qualquer pessoa passível de possibilidade de ir para além deles.

O clássico na escola é a transmissãoassimilação do saber sistematizado, mas ele só vai se dar a partir dos instrumentos e métodos que a escola tem de organizar seu currículo (SAVIANI, 2011). Por isso que, não basta a transmissão, é preciso que o aluno se aproprie desse conhecimento para criar a si mesmo no processo de superação por incorporação. E o que constitui o saber clássico? Ora, disciplinas escolares, tais como Português, Matemática, História, Geografia, Ciências, Artes e Literatura são exemplos que trazem consigo toda a história da humanidade, esta que torna-se capaz de gerar e impulsionar desenvolvimento humano (DUARTE, 2016).

Por fim, é importante ressaltar que, visar o conhecimento clássico, não é rechaçar o cotidiano e as práticas envoltas a ele, mas sim, instrumentalizar o aluno para que seja capaz de conduzir a sua vida cotidiana (SAVIANI, 2011).

\section{ARTE, LITERATURA, CATARSE E A FORMAÇÃO HUMANA}

Colocado então que a natureza do homem não é dada geneticamente, mas sim criada, por ele mesmo, na sua vida em sociedade; que as funções psíquicas superiores tornam-se tais por meio do processo histórico que vai do interpsíquico ao intrapsíquico, complexificando o psiquismo e o tornando pertencente ao gênero humano; e que o papel do processo educativo é potencializar desenvolvimento por meio do conhecimento clássico (episteme), surge a relevância do estudo da arte e da literatura para entender seus conceitos e a importância de seu ensino para o desenvolvimento humano como base para efetivação do artigo aqui proposto.

Para satisfazer as necessidades engendradas socialmente, o homem criou as objetivações genéricas como intermédio para tal, sendo capaz de utilizá-las para relacionar-se com sua realidade interna e externa (ANJOS, 2017). Estas objetivações podem ser empregadas em duas categorias: "em-si" e "para-si". Duarte (2013) pontua que estas podem ser relativas e tendenciais.

Pontuam-se tendenciais porque não são estados puros, mas sim tendências. A esfera "para-si" traz consigo a tendência de um processo de objetivação do gênero humano, ou seja, a tendência do indivíduo se objetivar conscientemente como pertencente a este gênero. Também são caracterizadas como relativas porque podem se referir tanto à relação entre o ser humano e a natureza, como ser utilizada no âmbito da prática social, em que o ser em-si pauta-se na espontaneidade e o para-si, na superação dela, onde é capaz de estabelecer uma relação consciente com seu meio (DUARTE, 2013).

As mediações que buscam satisfazer necessidades relacionadas ao pragmatismo e imediatismo do cotidiano são objetivações genéricas em si, tais como: uso e costumes de uma dada sociedade e a linguagem falada. Estas objetivações não exigem reflexões para sua apropriação (ANJOS; DUARTE, 2017). Os autores exemplificam a linguagem falada, mostrando que a criança, a priori, se apropria dessa objetivação de forma espontânea, tendo em vista que nessa etapa não há ensino e nem exigências de maior complexidade, tais como análises sintáticas e gramaticais.

A partir das objetivações genéricas emsi, e da constante superação das necessidades advindas socialmente, o homem foi capaz de criar objetivações cada vez mais complexas, tais como a arte, a ciência e a filosofia, essas que por sua vez, constituem as objetivações genéricas para-si. Essas objetivações são mais complexas e diferentemente do primeiro grupo exigem reflexões e a superação da espontaneidade e do cotidiano (DUARTE, 2013).

Esta última modalidade de mediação torna-se necessária a aquilo que Duarte (2013) a 
partir de postulados trazidos por Agnes Heller, chama de individualidade para-si. Com isso, Anjos e Duarte (2017, p. 118) ressaltam:

Todo ser humano forma sua individualidade em si, devido à apropriação, desde a mais tenra idade, das objetivações genéricas em si, e não há sociedade que possa existir sem a mediação de tais objetivações. A apropriação, pelo ser humano, das objetivações genéricas para si, forma a individualidade para si, ou seja, a máxima possibilidade da formação do indivíduo, uma individualidade que se relaciona com a cotidianidade de forma consciente, mediada pelas objetivações genéricas para si. Portanto, assim como o gênero humano ascendeu-se de sua genericidade em si à genericidade para si, importa que o indivíduo também ascenda de sua individualidade em si à individualidade para si.

Portanto, o indivíduo para-si torna-se capaz de ir além da espontaneidade estabelecida com a vida cotidiana, uma vez que internaliza diversas formas de comportamentos e maneiras de se utilizar instrumentos e utensílios criados pelo próprio homem, e estabelece uma relação consciente com o cotidiano, possibilitando a escolha de determinados pensamentos e práticas frente aos embates da vida cotidiana. Em última instância, a relação com instrumentos mediada pela genericidade para-si torna possível a condução da vida (ANJOS; DUARTE, 2017).

Importante colocar em pauta que a existência em si se faz necessária para viver o cotidiano (DUARTE, 2013), no entanto, para que possa conhecer a realidade além de sua aparência é necessário que se tenha as objetivações genéricas para si. É por meio de tais apropriações que o ser humano é capaz de chegar à complexidade psíquica do gênero humano até aquele momento (ANJOS, 2017).
Sendo então a arte pertencente ao grupo de objetivações genéricas para-si, que impulsionam o desenvolvimento da individualidade para-si e que traz consigo o aspecto de relação consciente com o cotidiano, é importante trazer à tona conceitos teóricos pertencentes à dois autores com bases epistemológicas comuns: Vigotski e Lukács. Os dois fomentam que o ensino da arte deve se dar por meio da catarse, conceito que será melhor descrito abaixo.

Partindo de uma crítica ao idealismo da época em que visava-se uma psicologia da arte centrada apenas no criador ou no espectador, Vigotski (1999) pontua que uma visão que entende o homem pelas suas determinações sociais deve visar a relação entre psicologia e arte pelo método objetivo-analítico: “ (...) da forma da obra de arte, passando pela análise funcional dos seus elementos e da estrutura, para a recriação da resposta estética e o estabelecimento das suas leis gerais" (VIGOTSKI, 1999, p. 27).

Portanto, para Vigotski (1999), a arte é a forma objetiva do subjetivo: a objetivação dos sentimentos humanos, que, quando, em primeira instância, são socializados, tornam-se parte do próprio psiquismo, permanecendo na dialética indivíduo-sociedade. Ela é capaz de, através de sua estrutura, impactar emoção estética por meio dos processos psicológicos, gerando organizações psíquicas mais elaboradas. Por isso:

quando a arte realiza a catarse e arrasta para esse fogo purificador as comoções mais íntimas e mais vitalmente importantes de uma alma individual, o seu efeito é um efeito social. A questão não se dá da maneira como representa a teoria do contágio, segundo a qual o sentimento que nasce em um indivíduo contagia a todos, torna-se social; ocorre exatamente 02 contrário. A refundição das emoções fora de nós realiza-se por força de um sentimento que foi objetivado, levado para fora de nós, materializado e fixado nos objetos externos da arte, que se tornaram instrumento da 
sociedade. A peculiaridade essencialíssima do homem, diferentemente do animal, consiste em que ele introduz e separa de seu corpo tanto o dispositivo da técnica quanto o dispositivo do conhecimento científico, que se tornaram instrumentos da sociedade. De igual maneira, a arte é uma técnica social do sentimento, um instrumento da sociedade através do qual incorpora ao ciclo da vida social os aspectos mais íntimos e pessoais do nosso ser. Seria mais correto dizer que o sentimento não se torna social, mas, ao contrário, torna-se pessoal,quando cada um de nós vivencia uma obra de arte, converte-se em pessoal sem com isto deixar de continuar social (VIGOTSKI, 1999, p. 315).

Lukács (1972) também concebe a catarse como categoria geral da estética e característica ao processo de recepção da obra de arte. Para este autor, a obra está a serviço da dialética: singular, universal e particular. Assim como Vigotski (1999) também se distancia de concepções endógenas e dualistas sobre tal assunto, e remete a obra de arte enquanto incorporação do universal no singular, o qual se tornará particular. Ou seja, a obra de arte em Lukács não se pauta somente no subjetivo ou só no social, mas como produto desta relação que acontece por meio do conhecimento historicamente acumulado (FERREIRA, 2012).

Por isso que, partindo de uma concepção dialética lukacsiana, a obra de arte, embora ligada ao desenvolvimento da humanidade, se torna única. Estudá-la é entender o desenvolvimento do homem em sua história e universalidade, fazendo com que o indivíduo estabeleça uma relação com um estímulo o qual não se faz presente na vida cotidiana (FERREIRA, 2012).

A "vida cotidiana" parece ser tema importante na ontologia-estética de Lukács
(1966), uma vez que ela é ponto de partida da arte e tende a ela retornar, produzindo um movimento capaz de ocasionar elevação na consciência de seu receptor: a catarse.

Partindo-se então do pressuposto de Lucáks referente ao "ser humano por inteiro", é possível dizer que na vida cotidiana e sua relação com as esferas em-si, o indivíduo não consegue estabelecer relações humanas com as atividades heterogêneas que são exigidas. E por isso que é preciso que haja uma homogeneização da sua relação com as objetivações para-si, no caso aqui dissertado, a arte, para relacionar-se de maneira plenamente humana com elas (FERREIRA, 2012; DUARTE, 2013).

A homogeneização é um processo de saída da cotidianidade ou de elevação acima dela. A superação de tal é uma exigência do desenvolvimento social de cada indivíduo, e essa exigência é posta pela própria sociedade, quando começa a apresentar determinado estágio de desenvolvimento histórico, de produção e reprodução da arte, da ciência e filosofia (FERREIRA, 2012). É neste processo de homogeneização que ocorre então a virada, a tomada de consciência, ou como os autores denominam: a catarse.

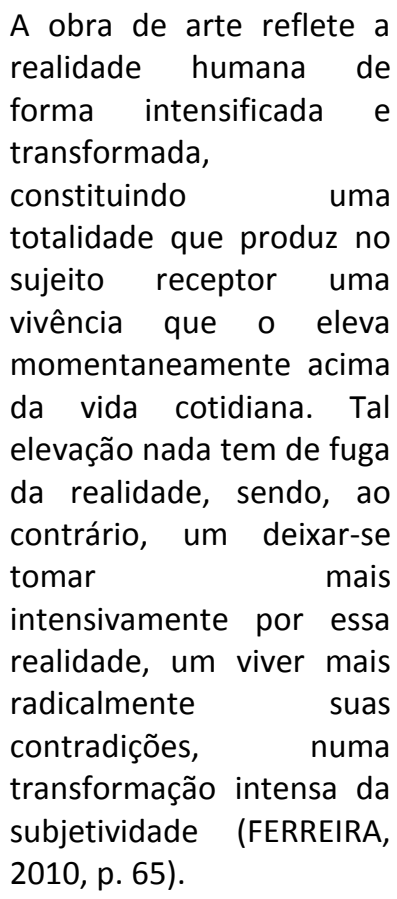

Vale ressaltar conceitos que também são importantes para o entendimento da recepção da arte e a vivência artística: conteúdo e forma. Em sua criação, o artista busca por meio do conteúdo atingir uma forma pretendida, de maneira que agrega os dois transformando-os em uma unidade íntegra. Já no caso da vivência 
receptiva, o caminho é inverso uma vez que a forma conduz o receptor a um determinado encontro com o conteúdo (FERREIRA, 2012). Nesse sentido, afirma Lukács (1996, p. 492):

Trate-se de poesia ou de pintura, de arquitetura ou de música, o receptor é introduzido em um mundo novo para ele e, ao mesmo tempo, que se torna rapidamente familiar. Quando essa familiaridade com o mundo da obra deixa de ser produzida, falta também todo efeito autenticamente estético.

O conteúdo designa a vivência artística, mas sem a forma adequada, a vivência perde algumas de suas características, tendo em vista que é por meio dessa unidade integra criada pelo autor da obra que se constituí a ascensão acima da vida cotidiana (FERREIRA, 2010).

Tendo colocado isso, a literatura, que faz-se pertencente às objetivações genéricas da arte, deve ter então a função, a partir da catarse, de desestruturar fetiches da realidade (FERREIRA, 2012). Como já se entendeu a obra literária enquanto construção humana que, em uma visão vigotskiana, objetiva sentimentos e os socializa ao indivíduo que se apropria de seus elementos, e em uma visão lukácsiana permanece na dialética "singular-universal-particular" cabe agora entender como se dá o ensino desta genericidade para si.

Atualmente, o ensino desta arte oscila entre dois modos: o primeiro relacionado às várias fases e tendências da literatura no decorrer da história e seus respectivos escritores pertencentes a cada uma (FERREIRA, 2012). A autora aponta que esse conhecimento se faz importante para o desenvolvimento do psiquismo, mas que reduzir-se a ele é deixar de lado, paradoxalmente, aquilo que constitui a existência do livro e toda a literatura, que é a vivência artística com as obras. O outro modo pauta-se no incentivo do hábito da leitura por prazer. Novamente, esse aspecto torna-se importante para se estabelecer relação com a obra de arte, mas quando foca-se como fim em si mesmo, deixa de visar o real sentido da arte, que é a desfetichização, a catarse, a apropriação de sentimentos e $o$ acesso às formas mais complexas de existir no mundo.

\section{CONCLUSÕES}

Resgatar um conceito, uma ideia ou reflexões acerca de uma temática, é, ao mesmo tempo, revivê-la, uma vez que esse feito está presente no próprio processo dialético de apropriação e objetivação do conhecimento historicamente acumulado. Resgatar a relação do ensino da literatura com o desenvolvimento humano é visar a continuidade da história social do homem, assim como de cada indivíduo pertencente a ela.

Assim, visando que o ponto de chegada seja o mesmo que o de partida, ainda não o é. Por isso, pontua-se: "Qual a relação do ensino da literatura com o desenvolvimento humano?" Foise possível pensar em duas palavras chave para essa questão: encontro e criação.

$\mathrm{O}$ encontro, em primeiro lugar, com os conteúdos construídos historicamente, com sentimentos que são socialmente demandados e desenvolvidos, com comportamentos que quando se tornam pertencentes ao indivíduo, ainda revelam o quão antiga a história humana é. $\mathrm{E}$ em segundo lugar, o encontro consigo mesmo, afinal, a homogeneização e o momento da virada concretizam aquilo que Vigotski $(1929$, p. 25) disse sobre a consciência da própria personalidade: "Eu me relaciono comigo tal como as pessoas relacionaram-se comigo".

A criação também acontece em dois momentos: primeiro, com cada indivíduo, a partir de sua participação social (tal como a leitura), construindo, continuando e desenvolvendo a história da humanidade, assim fazendo-se cada vez mais um ser integrante do gênero humano. $E$ segundo, o criar a si mesmo. Se o ser humano se supera com o devir, ele então não é só produto, mas também produtor de sua própria história.

A contemporaneidade mostra uma urgência em resgatar e retornar aos aportes teóricos clássicos e fundamentais à humanidade para entender a si mesma. O homem, como um ser histórico, é resultado de um processo que não deve jamais ser ignorado, esquecido ou não passado às suas próximas gerações, dado a importância desse fenômeno ressaltada ao longo desse artigo. A literatura como um clássico da humanidade deve mediar o desenvolvimento do homem, assim como sua autocriação, e isso exige que cada vez mais novos estudos sejam refeitos sobre a temática.

\section{REFERÊNCIAS}


ANJOS, R. E. O desenvolvimento psíquico na idade de transição e a formação da individualidade para-si: aportes teóricos para a educação escolar de adolescentes. 2013, $167 \mathrm{f}$. Dissertação (Mestrado) - Faculdade de Ciências e Letras, Universidade Estadual Paulista Júlio de Mesquita Filho, UNESP, Araraquara, 2013.

ANJOS, R. E. O desenvolvimento da personalidade na adolescência e a educação escolar. 2017, 198 f. Tese (Doutorado) Faculdade de Ciências e Letras, Universidade Estadual Paulista Júlio de Mesquita Filho, UNESP, Araraquara, 2017.

ANJOS, R. E; DUARTE, N. A teoria da individualidade para si como referência à análise da educação escolar de adolescentes. Nuances: Estudos Sobre Educação, Presidente Prudente, v. 28, n. 3, p. 115-132, 2017. https://doi.org/10.14572/nuances.v28i3.4183

DUARTE, N. As pedagogias do "aprender a aprender" e algumas ilusões da assim chamada sociedade do conhecimento. Rev. Bras. Educ., Rio de Janeiro, n. 18, p. 35-40, dez. 2001 a. https://doi.org/10.1590/S1413-

$\underline{24782001000300004}$

DUARTE, N. Vigotski e o "Aprender a Aprender" Crítica às Apropriações Neoliberais e PósModernas da Teoria Vigotskiana. 2a ed. rev. e ampl. Campinas, SP: Autores Associados, 2001b.

DUARTE, N. Individualidade para si: contribuição a uma teoria histórico-social da formação do indivíduo. 3. ed. rev. Campinas, SP: Autores Associados, 2013.

DUARTE, N. Os conteúdos escolares e a ressuirreção dos mortos. Campinas, SP: Autores Associados, 2016a.

DUARTE, N. Relações entre conhecimento escolar e liberdade. Cadernos de Pesquisa, São Paulo, v. 46, n. 159, p. 78-102, mar. 2016b. https://doi.org/10.1590/198053143508

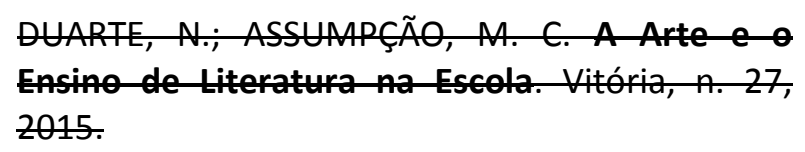
2015.

FERREIRA, N. B. P. A arte e a formação humana: implicações para o ensino da literatura. São
Paulo: Editora UNESP; São Paulo: Cultura Acadêmica, 2010.

FERREIRA, N. B. P. A catarse estética e a pedagogia histórico-crítica: contribuições para o ensino da literatura. 2012, 172 f. Tese (Doutorado), Faculdade de Ciências e Letras, Universidade Estadual Paulista Júlio de Mesquita Filho, UNESP, Araraquara, 2012.

LEONTIEV, A. O desenvolvimento do psiquismo. Lisboa: Horizonte, 1978.

. Actividad, conciencia e

personalidad. Havana: Editorial Pueblo y Educación, 1983

LUKÁCS, G. Estética: la peculiaridad de lo estético. Vol. 1: Questiones Preliminares y de Principio. Traduzido do original em alemão por Manuel Sacristán. Barcelona: Grijalbo, 1966.

LUKÁCS, G. Estetica: la Peculiaridad de lo Estetico. Vol. 2: Problemas de La Mímesis. Traduzido do original em alemão por Manuel Sacristán. 2. ed. Barcelona: Grijalbo, 1972.

LUKÁCS, G. Estetica: la peculiaridad de lo estetico: problemas de la mímesis. Barcelona: Grijalbo, 1966.

LUKÁCS, G. Para uma ontologia do ser social II. São Paulo: Boitempo, 2013.

LURIA, A. R. Curso de psicologia geral v. 1: introdução evolucionista à psicologia. Rio de Janeiro: Civilização Brasileira, 1979.

MARTINS, L. M. O desenvolvimento do psiquismo e a educação escolar: contribuições à luz da psicologia histórico-cultural e da pedagogia histórico-crítica. Campinas: Autores Associados, 2013.

https://doi.org/10.20396/rho.v13i52.8640243

MARTINS, L. M. A internalização de signos como intermediação entre a psicologia histórico cultural e pedagogia histórico-crítica. Germinal: Marxismo e Educação em Debate, Salvador, v. 7, n.1, p. 44-57, jun. 2015. https://doi.org/10.9771/gmed.v7i1.12291

MARTINS, L. M.; DUARTE, N. Orgs. Formação de professores: limites contemporâneos e 
alternativas necessárias [online]. São Paulo: Editora UNESP; São Paulo: Cultura Acadêmica, 2010.

MARTINS, L. M.; RABATINI, V. G. A concepção de cultura em Vigotski: contribuições para a educação escolar. Rev. psicol. polít., São Paulo , v. 11, n. 22, p. 345-358, dez. 2011.

PASQUALINI, J. C.; MAZZEU, L. T. B. Em defesa da escola: uma análise histórico-crítica da educação escolar. Educação em revista, Marília, v. 9, n. 1, p. 77-92, 2008.

SAVIANI, D. Escola e democracia: teorias da educação, curvatura da vara, onze teses sobre a educação política. Campinas, SP: Autores Associados, 2006.

SAVIANI, D. Pedagogia histórico - crítica: primeiras aproximações. 11. ed. rev. Campinas, SP: Autores Associados, 2011.

SAVIANI, D. Pedagogia histórico-crítica na educação do campo. In: SEMINÁRIO NACIONAL DE ESTUDOS E PESQUISAS SOBRE EDUCAÇÃO DO CAMPO, 2013, São Carlos, Anais... São Carlos, 16 out. 2013.

SAVIANI, D. Psicologia Concreta do Homem (Manuscritos de 1929). Educação e Sociedade, n. 71, 1929.

STEIMBACH, A. A. 0 processo de ensino numa perspectiva histórico-crítica. 2008. Acesso em 04 de Maio de 2018. Disponível em: http://www.famper.com.br/download/allan.pdf

VIGOTSKI, L. S. Obras escogidas. Tomo III. Madrid, Visor, 1995.

VIGOTSKI, L. S. Psicologia da arte. São Paulo: Martins Fontes, 1999.

VIGOTSKI, L. S. Teoria e método em psicologia. São Paulo: Martins Fontes, 2004, p. 93- 101.

VIGOTSKI, L. S. Aprendizagem e desenvolvimento intelectual na idade escolar. In: VIGOTSKII, L. S.; LURIA, A. R.; LEONTIEV, A. N. Linguagem, desenvolvimento e aprendizagem. 10. ed. São Paulo: Ícone, 2006. p. 103-117.
VIGOTSKI, L. S. Linguagem, desenvolvimento e aprendizagem. 11. ed. São Paulo: Ícone, 2010. 